\title{
The Ramifications of Reservations to Human Rights Treaties
}

\author{
Lara Mullins* \\ https://doi.org/10.21827/GroJIL.8.1.150-165
}

\begin{abstract}
Keywords
HUMAN RIGHTS; TREATIES; RESERVATIONS TO HUMAN RIGHTS TREATIES;
\end{abstract}

\begin{abstract}
This paper discusses the legal ramifications of reservations to multilateral human rights treaties. It examines the approach of the International Court of Justice (ICJ), compared to that of the European Court of Human Rights (ECtHR), in light of the general practice in international law relating to reservations and the International Law Commission's commentary. The paper then discusses the scope for change and growth, given the nature of the two different approaches. Once it has set out the current law it describes the role of the evolving moral, social and political climate in society and the effect that it has on the conversation around human rights and treaty reservations. It answers three main questions around reservations: first, whether reservations are allowed; second, the conditions under which they are allowed; and third, if reservations are not allowed, whether the invalid reservation cancels a party's membership of the treaty. Having answered these three questions, the paper draws to the conclusion that, ultimately, for international law to continue to be effective, state sovereignty must be given the utmost respect and importance in relation to reservations. With the current polarisation of the political climate, as is evidenced by the traditionally liberal states' leaning towards conservative values, as in Britain and the United States, a push by the ECtHR to sever reservations from treaties and still bind the state will only alienate key players from the international stage. At face value, one may be inclined to think that the stringent protection of human rights values and limiting the reservations to such values is beneficial but, in reality, this would make participation in the international framework unappealing to states as their sovereignty would be infringed. Therefore, the ICJ's approach is advantageous as it understands the role of reservations in achieving participation and it also understands the state practice element. Thus, in line with the ILC commentary and the ICJ's judgements, the ECtHR's recent rulings will not become the international law norm and state sovereignty with respect to reservations will continue to prevail.
\end{abstract}

\section{Introduction}

This essay discusses the legal ramifications of reservations to multilateral human rights treaties. It will examine the approach of the International Court of Justice (ICJ), compared to that of the European Court of Human Rights (ECtHR), in light of the general practice in international law relating to reservations and the International Law Commission's commentary. The paper will then discuss the scope for change and growth, given the nature of the two different approaches. Once the current law has been described, the role of the evolving moral, social and political climate in society and the effect that it has on the conversation around human rights and treaty reservations will be analysed. The paper will conclude with a discussion of what can be expected in the future, given the varying approaches and societal changes. 
This paper seeks to answer three main questions in relation to reservations: first, whether reservations are allowed; second, the conditions under which they are allowed; and third, if reservations are not allowed, whether the invalid reservation cancels a party's membership of the treaty.

\section{General Background on Reservations}

Before beginning the enquiry into these three questions, some general context on reservations and the legal setting in which they are analysed is necessary. A reservation results in the absence of obligations that the treaty would otherwise entail. ${ }^{1}$ International law can be applied in three main ways when analysing a legal problem: the doctrinal approach, the State practice approach and the policy-oriented approach. The doctrinal approach seeks to provide 'a critical conceptual analysis of all relevant legislation and case law to reveal a statement of the law relevant to the matter under investigation' . In essence, this approach adheres closely to the letter of the law. State practice is 'a pattern of behaviour by states which, if accompanied by a conviction by those states that their behaviour is required as a matter of law, may give rise to customary international law'. ${ }^{3}$ The State practice approach is the practical implementation of State practice to form the basis of a legal decision. In order for a general principle to be established as State practice, the court must ascertain that the practice is 'recognized by civilized nations', which in practice means that the principle can be found in 'diverse legal families'. ${ }^{4}$ The policyoriented approach looks at what the law ought to be, given the public policy of the society, and seeks to shape and enforce the law accordingly. ${ }^{5}$

Ultimately, this paper will argue for a State practice and policy-oriented approach. It argues that to rely on policy alone would infringe on certainty and State sovereignty, which would lead to a lack of State participation. This would destroy the foundation of international law and the entire system would cease to function effectively. This will be elaborated upon in the context of the Courts' approaches and the ILC commentary below. The general practice around treaties will be discussed first, with reference to the three questions raised in the introduction.

The Vienna Convention on the Law of Treaties (VCLT) ${ }^{6}$ is an authoritative instrument on international law treaties and forms part of international customary law (making it binding on all States whether they have ratified it or not). ${ }^{7}$ The VCLT defines a reservation as 'a unilateral statement, however phrased or named, made by a State, when signing, ratifying, accepting, approving or acceding to a treaty, whereby it purports to exclude or to modify the legal effect of certain provisions of the treaty in their application

* University of Cape Town.

1 International Law Commission, 'Report of the International Law Commission on the Work of its Fiftieth Session' (23 July 1998) A/CN.4/SER.A/1998/Add.1 (Part 2) paras 490-504.

2 Terry Hutchinson, The Doctrinal Method: Incorporating Interdisciplinary Methods in Reforming the Law' (2015) 8(3) The Erasmus Law Review 130, 131.

3 John Currie, Public International Law (2nd edn, Irwin Law 2008) 321.

4 Katerina Linos, 'How to Select and Develop International Law Case Studies: Lessons from Comparative Law and Comparative Politics' (2015) The American Journal of International Law 475.

5 Myres McDougal, 'Law as a Process of Decision: A Policy-Oriented Approach to Legal Study' (1956) Natural Law Forum 53.

6 Vienna Convention on the Law of Treaties (adopted 23 May 1969, entered into force 27 January 1980) 1155 UNTS 331 (Vienna Convention) art 33.

7 David Jonas \& Thomas Saunders, 'The Object and Purpose of a Treaty: The Interpretive Methods' (2010) Vanderbilt Journal of Transitional Law 572. 
to that State' ${ }^{8}$ Due to State sovereignty a reservation is always allowed, except in the following circumstances: (1) the treaty prohibits all reservations; (2) the treaty allows only certain reservations but not including the one at hand; or (3) the reservation is incompatible with the object and purpose of the treaty. ${ }^{9}$ Reservations cannot be made after a State has accepted a treaty; the reservation must be made at the time that the treaty is being signed and negotiated by the State. Traditionally, a State that wants to attach a reservation that is not permissible will not be permitted to become a party to the treaty unless all the other nation-States that are parties to the treaty agree to the reservation. ${ }^{10}$ However, this traditional position has been challenged in practice, and these challenges will be discussed below when answering the third question raised in the introduction.

As previously discussed, Article 19(c) of the VCLT created 'the object and purpose' test as the default rule for deciding whether a reservation was permissible or not. This applied to all treaties, ${ }^{11}$ not only those with a 'humanitarian or civilizing purpose' ${ }^{12}$ The other States that were parties to the treaty decided whether a reservation passed the test. This obviously politicises reservations, as States have the power to object on any basis they see fit. However, there is a cap on this, as Article 20(5) of the VCLT states that there is a 12-month time limit on State objections. ${ }^{13}$ If other States make no objections within twelve months, the reservation is considered to be accepted by the non-objecting State; this is also known as 'the twelve month tacit consent rule'. ${ }^{14}$ Three doctrines have been developed in response to the consequences of a State making a reservation that is objected to: permissibility, opposability and severability. ${ }^{15}$ When reservations are regarded as unacceptable, one of these three doctrines is employed.

The permissibility doctrine holds that a reservation that is irreconcilable with the 'object and purpose' test is invalid and has no legal effect. This is the case whether other States object or not, and 'this view stems from the natural reading of Vienna Convention Article 19(c) and suggests that incompatible reservations are void ab initio or are not proper reservations'. ${ }^{16}$ The opposability doctrine, by contrast, argues that if another State objects to a reservation then the State that made the reservation will no longer be a party to the treaty. ${ }^{17}$ The severability approach holds that if an invalid reservation is objected to then the reserving State 'will be bound to the treaty without the benefit of the reservation'. ${ }^{18}$ The severability approach is the one employed by the ECtHR when finding a reservation impermissible and this is evident from decisions of the ECtHR, which will be discussed later in the paper.

The Reservations to the Convention on the Prevention and Punishment of the Crime of Genocide Advisory Opinion was handed down by the ICJ in 1951 and showed the

\footnotetext{
8 Vienna Convention (n 6) art 2(1)(d).

9 ibid art 19(c).

10 ibid art 20(2).

11 ibid art 1.

12 Reservations to the Convention on the Prevention and Punishment of the Crime of Genocide (Advisory Opinion) 1951 <icj-cij.org/files/case-related/12/012-19510528-ADV-01-00-EN.pdf > accessed 14 July 2020 [7].

13 Vienna Convention (n 6) art 20(5).

14 Belinda Clark 'The Vienna Convention Reservations Regime and the Convention on Discrimination Against Women' (1991) The American Journal of International Law 312.

15 Kasey McCall-Smith, 'Severing Reservations' (2014) International and Comparative Law Quarterly 2.

16 ibid 12.

17 ibid 14.

18 ibid 17.
} 
application of the general rules surrounding reservations that are outlined above. ${ }^{19}$ In summary, the Court held that where treaties do not explicitly state that reservations can be made, one cannot 'infer that they are prohibited' ${ }^{20}$ This means that if there is no specific clause indicating that reservations of any kind are forbidden, it is assumed that they will be allowed. The Court then analysed the Genocide Convention to see whether it allowed for reservations by implication. The Court stated that being stricter with reservations to the Convention would deter States from signing up to the treaty and this would nullify the treaty's objectives. ${ }^{21}$ The Court then spoke about the legal effect of objections from other States to any particular reservations. It held that other States were within their rights to object, but since the goal was to have as many nations becoming parties to this Convention as possible, the objection would affect only the two States concerned as they themselves would decide whether they considered the reserving State to be a party. ${ }^{22}$ Ultimately, the issue was whether any State felt that the reservation of another State went against the 'object and purpose' of the Convention and then each member State would decide, on the basis of its individual appraisals of the reservation, whether it deemed the reservation to be objectionable or not.

This decision echoes the general rules relating to reservations set out above, but also allows for a broader range of reservations in an attempt to respect State sovereignty and to encourage as many States as possible to consent to being part of a global legal framework. Allowing this broader range of reservations in the case of the Genocide Convention is evidenced by the fact that the States were not barred from becoming parties to the treaty, even though all nation-States did not accept their reservations.

The Court states at the outset that its decision to widen the range of permissible reservations and apply it only to the two States in question is 'expressly limited by the terms of the Resolution of the General Assembly to the Convention on Genocide'. ${ }^{23}$ This approach was therefore adopted given the specific circumstances surrounding the Convention, rather than being the norm. However, the judgment's reasoning is persuasive and shows the multitude of considerations at play when deciding how to handle reservations. The decision also confirms that the Court recognises 'that some treaties have special character and that they aim to achieve wide participation of the states therein'. ${ }^{24}$ This was the first instance where reservations were treated differently due to the magnitude of the rights addressed by the instrument concerned, and shows that in order to achieve widespread compliance with what were considered integral values, changes had to be made to the status quo.

Subsequently, the United Nations Human Rights Commission, the body that administers and interprets the International Covenant on Civil and Political Rights, has adopted the approach that an inadmissible reservation to the Covenant will mean that the reserving State is still party to the treaty, but without the benefit of the reservation. ${ }^{25}$ This view is controversial, given that reservations are seen as the State's prerogative, and inadmissible reservations would generally exclude them from a treaty, rather than binding

19 Reservations to the Convention on the Prevention and Punishment of the Crime of Genocide (n 12).

20 ibid 6.

21 ibid 8.

22 ibid 10.

23 ibid 5.

24 Ineta Ziemele and Lasma Liede, 'Reservations to Human Rights Treaties: From Draft Guideline 3.1.12 to Guideline 3.1.5.6' (2013) European Journal of International Law 1137.

25 Elena Baylis, 'General Comment 24: Confronting the Problem of Reservations to Human Rights Treaties' (1999) 17 Berkeley Journal of International Law 277-278. 
them yet disregarding the reservation. However, this approach does not seem to be applied beyond the scope of human rights treaties. This could indicate that reservations to treaties of this nature (that is, treaties that are seen to be of the utmost importance due to the character of the rights they protect) are being handled in an atypical manner. In General Comment No 24, the Human Rights Committee stated, when discussing the substance of human rights treaties, that 'such treaties, and the Covenant specifically, are not a web of inter-state exchanges of mutual obligations. They concern the endowment of individuals with rights. The principle of inter-state reciprocity has no place [there] ${ }^{\prime 26}$ In light of this changing view of human rights treaties, it has been argued that the VCLT is incapable of providing the necessary framework for handling reservations of this nature because many of its provisions are written to reflect the operation of a multilateral treaty between States in issues where States act in their own interest in respect of other States, where there are no third parties with their own rights or obligations involved and where the treaty does not establish an independent international mechanism for its application and interpretation. ${ }^{27}$

Here it is necessary to note that the human rights culture was borne from the trauma of the Second World War and the purpose of international law was to ensure State accountability to other States for atrocities committed during and after the war. ${ }^{28}$ International law has only recently evolved into a means of regulating and universalising social, economic and political rights, which States are required to guarantee for their people. $^{29}$

Therefore, as law and society evolve, there are more instances of reservations being prohibited. While this may deter States from becoming parties to the treaties, it has been argued that the fact that the conventions are intended to be legislative in nature means that enforcing the standardised application of their regulations is vital, and thus the growing resistance to reservations is necessary. ${ }^{30}$ Furthermore, it can be argued that the complexity of multilateral treaties and the need for a multitude of parties with varying interests to compromise further shows the need to limit reservations. Rather than allowing countries to reserve as they wish, these limitations on reservations could streamline the creation and application of international human rights law. However, the United Nations Convention on the Law of the Sea is an example of how a strict approach to excluding reservations can backfire. $^{31}$ The United States did not become a party to the Convention due to the provisions on mining the deep seabed, to which no reservations could be made. ${ }^{32}$ If strict rules are applied to reservations, States will often willingly exclude themselves from treaties that are of great importance. As a result, they are not bound at all, as opposed to at least being bound in part.

The examples above show the tension between the growing desire to hold States more strictly to treaties and the need to not deter States from engaging in international law and agreeing to be parties to treaties. Several judges have taken issue with the strict banning of reservations, such as Sir Hersch Lauterpacht in his Separate Opinion in the Norwegian Loans case. Judge Lauterpacht stated that the particular clause at hand could be severed

26 Office of the High Commissioner of Human Rights 'General Comment No 24' (11 November 1994) CCPR/C/21/Rev1/Add6 para 17.

27 Ziemele and Liede (n 24) 1136.

$28 \quad$ McCall-Smith (n 15) 4.

29 ibid.

$30 \quad$ OHCHR (n 26) para 17.

31 United Nations Convention on the Law of the Sea (adopted 10 December 1982, entered into force 16 November 1994) 1833 UNTS 397.

32 David Sandalow, 'Law of sthe Sea Convention: Should the US Join' (Brookings, 2004) <www.brookings.edu/research/law-of-the-sea-convention-should-the-u-s-join/> accessed 23 July 2020. 
and the treaty could then be deemed to have been accepted, but the will and intention of the accepting State were crucial in deciding if this was the case. ${ }^{33}$ This shows that the 'content of the state's consent plays a significant role in determining the effects of impermissible reservations. ${ }^{34}$ The Interhandel case followed this line of reasoning and looked closely at the intention of the United States when it reserved a particular aspect of the treaty. ${ }^{35}$ At this point, it is important to acknowledge that both these cases dealt with a different kind of reservation to the ones related to treaty obligations that have been discussed thus far. These cases dealt with the acceptance of the ICJ's jurisdiction under Article 36 of the Statute of the ICJ. ${ }^{36}$ When the ICJ's cases are discussed further below, it will be explained why these cases are still relevant to the topic under discussion, despite this difference.

The approach adopted in the cases above appears to be contrary to that of the VCLT, since the VCLT states that an impermissible reservation excludes the State from being party to the treaty, unless all other state-parties agree to the reservation. ${ }^{37}$ However, the object and purpose of the treaty must also be taken into account. ${ }^{38}$ By looking at the object and purpose of the treaty, as was discussed earlier in relation to the Genocide Convention Advisory Opinion, ${ }^{39}$ the special character of the treaty would be taken into account when deciding whether the reservation fell within the ambit of permitted reservations, or how the reservation could be addressed to maximise State participation. When looking at the object and purpose, the courts may alter the requirements that affect the validity of a reservation accordingly, as was done in the Genocide Convention Advisory Opinion.

Having provided the legal context, I will now answer the three questions posed previously.

The first question is whether reservations are permitted. International law has accepted that reservations to multilateral treaties are allowed and human rights treaties are not exempt from this. The Genocide Convention Opinion and the VCTL recognise that reservations to human rights treaties are always permitted where treaties are silent on the matter. ${ }^{40}$

The second question deals with the conditions under which reservations are permitted. Reservations are allowed unless the treaty states otherwise. The drafters of a treaty can limit a State's ability to reserve on certain matters. The State must then decide whether it wishes to become a party to the instrument in spite of its inability to reserve on certain matters. Furthermore, according to the VCLT, the reservation of the State may not go against the object and purpose of the treaty. ${ }^{41}$ However, when looking at the commentary of the International Law Commission (ILC), it becomes apparent that this requirement is often seen as vague and unhelpful. ${ }^{42}$

The third question -whether or not an invalid reservation cancels a party's membership to a treaty- is more complex than the first two and will be analysed in the

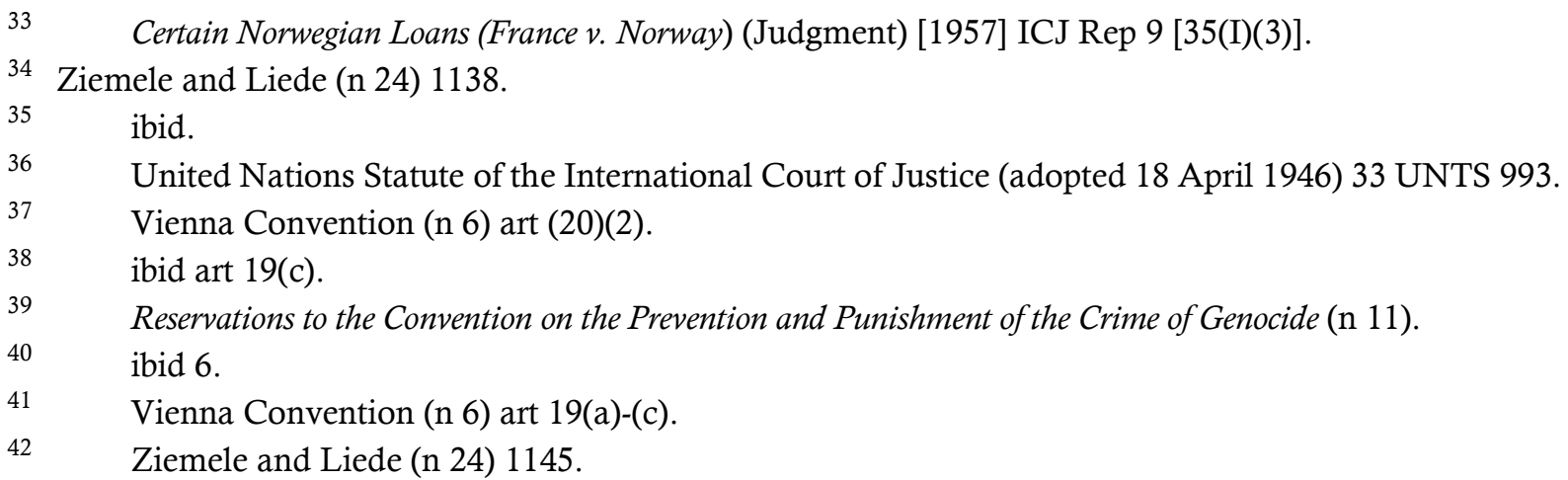


remainder of the paper. This question has led to two very different approaches by the ICJ and the ECtHR. This paper will seek to provide the necessary context to answer the third question and will also comment on the proposed ambiguity of the second.

In 2011, the ILC established a working group on reservations to treaties to work on a final rendition of the Guide to Practice that was originally adopted in 2010, including the changes proposed by the Special Rapporteur subsequent to the oral and written observations that have been made by States on the topic since $1995 .{ }^{43}$ In August 2011, the ILC decided to recommend that the General Assembly take note of the Guide to Practice and ensure that it was disseminated as widely as possible, in terms of Article 23 of the United Nations Charter. ${ }^{44}$

The ILC specifically chose to create 'guidelines accompanied by commentaries', ${ }^{45}$ rather than a binding instrument; this was unlike the ILC's usual practice. The Guide to Practice was intentionally created as a combination of hard law and soft recommendations. The Special Rapporteur explained the reasons for this in his preliminary report. He noted that "what should be termed a "modest approach" certainly offers great advantages' ${ }^{46}$ In summary, these advantages were the following: formally changing the existing provisions would create immense technical difficulties and might deter State participation in international law; clarifying existing principles is more helpful than changing them; and State representatives had made it clear to the ILC that they were happy with the status quo because, while it created ambiguity, this ambiguity had never led to a serious dispute and international law treaties had enjoyed widespread participation. ${ }^{47}$

The ILC stated that it was not recalling the provisions on reservations contained in the VCLT ${ }^{48}$ It referenced the findings of the Special Rapporteur's report and the reasons for the 'modest approach' ${ }^{49}$ It then stated that it was fully aware that there had to be an equal weighting between the integrity of a treaty and the need for the widespread participation of States. The ILC specifically acknowledged 'the efforts made in recent years, including within the framework of international organizations and human rights treaty bodies, to encourage such a dialogue ${ }^{50}$ With this in mind, the ILC then stated that the reservations should be formulated as narrowly as possible. In addition, statements of reasons for a reservation should be given that explain why the reservation is necessary, as this is important for ascertaining the validity of a reservation. States should also periodically review their reservations 'with a view of limiting their scope or withdrawing them where appropriate'. ${ }^{51}$

In light of the concerns frequently expressed by other States, international organisations and monitoring bodies can assist in determining the validity of reservations.

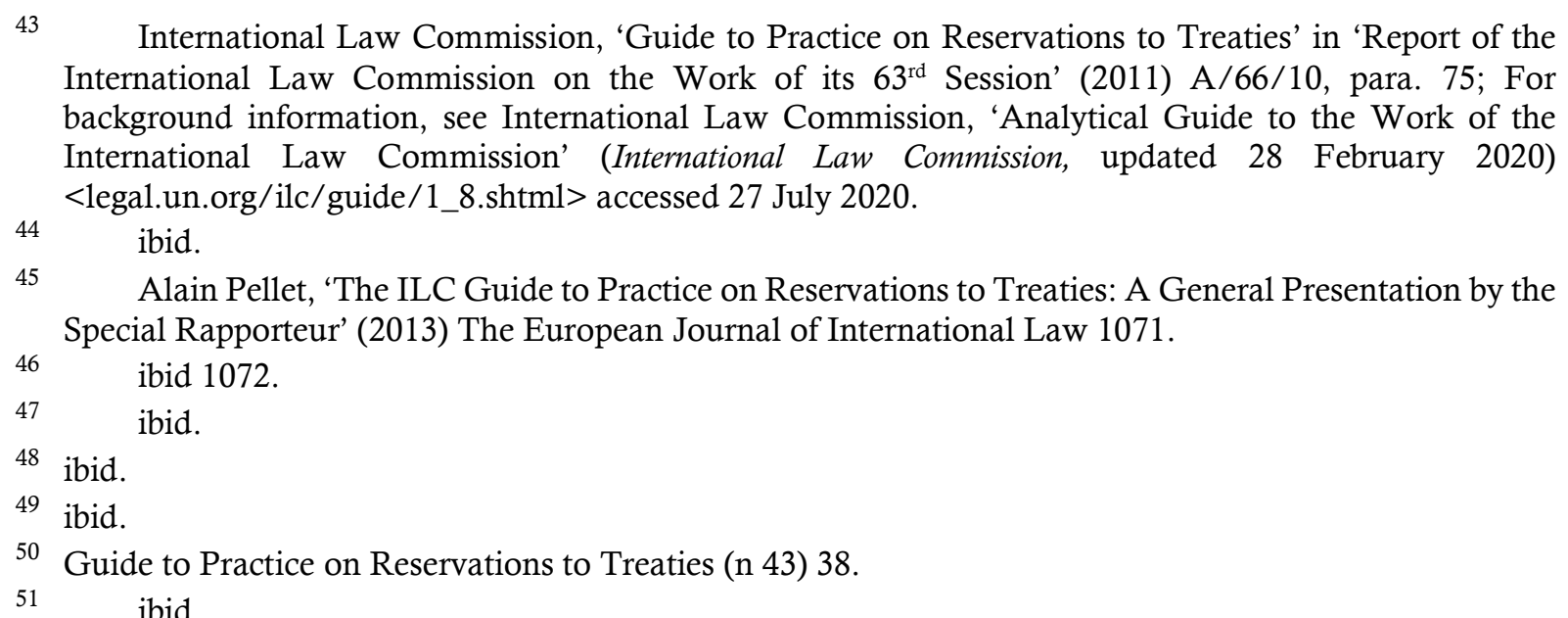


The bodies tasked with enforcing the treaties can express their concerns about the reservation and ask for clarification. These bodies can also encourage withdrawals of reservations, the limiting of their scope, or the reconsideration of proposed reservations. The ILC noted that there should be close cooperation between the bodies to exchange their evolving views on reservations, and recommended that ' $[\mathrm{t}]$ he General Assembly call upon States and international organizations, as well as monitoring bodies, to initiate and pursue such a reservations dialogue in a pragmatic and transparent manner' ${ }^{52}$

The Rapporteur took the position that the approach to reservations established by the VCLT was flexible enough to accommodate the special character and purpose of human rights treaties. While it was argued that limiting contractual thinking had often become part of the law of treaties, and by extension reservations, the ILC's interpretation of the VCLT discarded this more narrow, contractual approach. ${ }^{53}$ The normal order of affairs, or what some may call the ordre public, was maintained by the notion that the VCLT could be interpreted more widely so as to apply to the special character of human rights treaties ${ }^{54}$ Some have argued that the VCLT was drafted too long ago to reflect the growing importance of a human rights culture in recent years. For example, the development of socio-economic rights means that States are accountable to their citizens, as opposed to only other States. ${ }^{55}$ The ILC's broader interpretation of and guidelines around the VCLT's 'object and purpose' clause clearly indicated that the 'object and purpose' must take into account the special character of the treaties and the changing society that led to this special character.

This changing society can be seen in the role of the human rights treaty bodies. Human rights treaty bodies are 'committees of independent experts that monitor implementation of the core international human rights treaties'. ${ }^{56}$ The role of the treaty bodies was discussed by the ILC, especially in relation to reservations, as these bodies were not envisaged when the VCLT was drafted. The ILC looked at the effects of this development on international law practice with reference to the usual approach, which looked at the consequences of reservations for States that were parties to the treaty and their obligations to each other. Human rights treaty bodies, however, are concerned with holding the State accountable to its people. ${ }^{57}$ Thus, there is tension between the standard or old order- of affairs and the new order, which requires that different obligations be fulfilled by the State.

In essence, the ILC has noted that the VCLT is malleable and can accommodate the special character of human rights treaties. The ILC has left the hard law of the VCLT intact but added additional guidelines, which give more scope, interpretation and practical implementation to the broad and vague provisions of the VCLT. These guidelines are a clear reflection of the shift in the international sphere with regards to how reservations are being addressed. While keeping the conventions of the VCLT alive, the guidelines broaden their ambit by interpreting the object and purpose of a treaty. The guidelines also show that they are expected to evolve over time. They focus on human rights and the importance of the accountability of States for the reservations they make in this sphere.

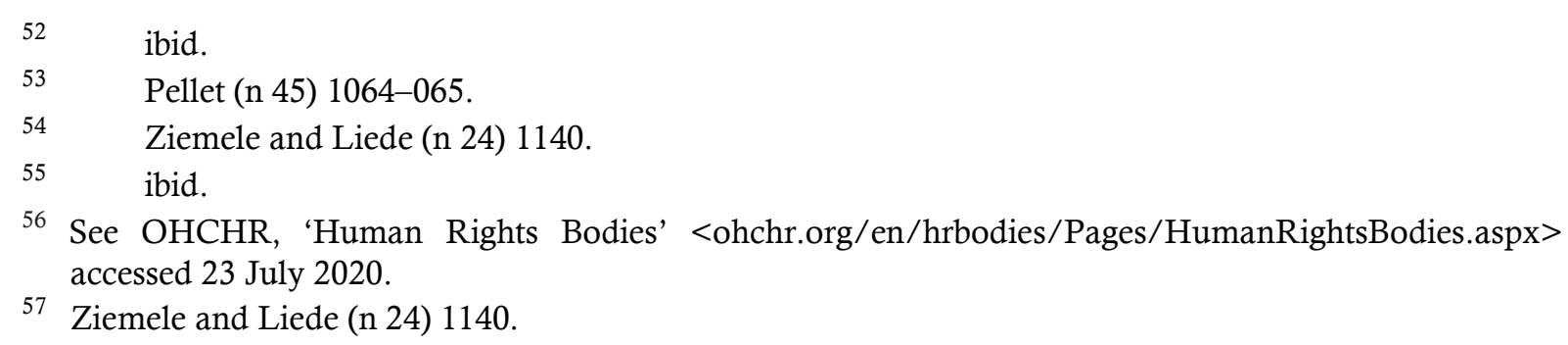


Overall, the ILC recognises that maintaining certainty and sovereignty when it comes to reservations is key in encouraging State participation, which is the backbone of international law. However, the ILC also sees that a practical guide is necessary to link the old to the new and to create substantive ways of addressing the issues of the future, given that there are new obligations on States, such as social and political rights. These changes include the increased participation of citizens and the obligations that States owe to their citizens, as opposed to the old order of affairs at the time the VCLT was drafted, when States owed obligations only to each other. Thus, it has been established that reservations are allowed and the conditions under which they operate are either governed by the VCLT or can be found within the treaty itself.

The next section of this paper will look at the approach of the ICJ and the ECtHR to reservations, and how the hard law and the soft law is being interpreted by the Courts. I will look at whether the actions of the Courts reflect what has been discussed above and whether there is scope for growth in terms of how reservations are handled. The ILC's commentary has not yet been implemented by the General Assembly, meaning that it amounts to no more than a set of recommendations with little authority. However, as stated above, the ILC intended it to be more of a guide than an instrument. However, there are other instances where a commentary of this nature has amounted to opinio juris. This statement will be elaborated upon below, but in order to do this an examination of the Courts and their jurisprudence is necessary.

\section{The Approach of the ECtHR}

The ECtHR is a court of law that relies on legal sources in its analysis. It is a constitutional panel that interprets the provisions of the European Convention on the Protection of Human Rights and Fundamental Freedoms (the European Convention). ${ }^{58}$ As seen above, the question of human rights law and how it relates to any major legal instrument is complex and requires interpretation:

...put simply, it is difficult for a government to ratify an instrument which affirms the profound belief of its members in those Fundamental Freedoms which are the foundation of justice and peace in the world and at the same time make reservations to those fundamental freedoms as if they were no more important than any one of the routine provisions in the myriad of agreements that most governments enter into every year without the appearance of some, if not a considerable, degree of insincerity..$^{59}$

When the empowering treaty, the European Convention, was proposed, it was meant to universalise human rights law throughout Europe and it was made clear that no reservations could be made to protect national law that was contrary to the Convention. ${ }^{60}$ It was later argued that the courts extended the scope of the Convention and that State parties never intended to assume certain obligations when they ratified the Convention. Those who originally ratified the Convention without the benefit of making extensive reservations felt that those who ratified later had an unfair advantage in terms of reservations, now that the courts had increased the ambit of the Convention. This led some States to consider withdrawing from the Convention so that they could re-ratify with the

58 Convention for the Protection of Human Rights and Fundamental Freedoms (European Convention on Human Rights, as amended) (ECHR).

59 Judge Ronald MacDonald, 'Reservations Under the European Convention on Human Rights' (1988) Revue Belge de Droit International 429.

60 Ziemele and Liede (n 24) 1138. 
benefit of being able to make more reservations. ${ }^{61}$ Distinguished scholars have commented that this development is concerning. Frowein, for instance, has drawn attention to this issue and opines that this conduct 'may run counter to the very essence of what the Convention is about' ${ }^{62} \mathrm{He}$ is uncertain whether reservations are really in line with the objective of the Convention and sees the 'possibility of unilateral derogation through reservations' $^{63}$ as a fundamental weakness of the European Convention. Before considering his opinion, I will outline the requirements for making reservations in terms of the Convention.

The European Convention states that there are four requirements for a reservation to be valid: (1) it must be made at the moment it is signed or ratified; (2) it must relate to specific laws in force at the moment of ratification; (3) it must not be a reservation of a general character; and (4) it must contain a brief statement of the law concerned. ${ }^{64}$ These criteria seem to be significantly different from those seen in other human rights treaties. The Convention does not refer to the 'object and purpose' clause of the VCLT, but it can be assumed that the clause applies since it is part of customary international law. This leads us to the third question that the paper seeks to address: if a reservation is not allowed due to not fulfilling these requirements and those of the VCLT, is the reserving State consequently no longer party to the treaty?

In the Temeltasch ${ }^{65}$ and Belilos ${ }^{66}$ cases, both the European Commission of Human Rights and the ECtHR chose not to address the argument made by the Swiss Government that its interpretative declarations were not offensive in any way to the object and purpose of the European Convention and that other States had implicitly acknowledged its declarations by raising no objections. Thus, Switzerland's argument was that there had been a tacit acceptance of its terms as no issues were brought up by other States. The dissenting opinion of members of the European Commission ( $\mathrm{Mr}$ Kiernan and $\mathrm{Mr}$ Gözübüyük) in the Temeltasch case shows that the members wanted more clarity about reservations to the European Convention.

The European Convention organs were among the first to examine the consequences of impermissible reservations to any given treaty. In the Belilos case, the Swiss Government submitted an interpretative declaration, which was seen to be a reservation that did not comply with the Article 57 criteria and was therefore invalid. ${ }^{67}$ The reservation in this case was to Article 6(1) of the European Convention. Switzerland argued that it was severable because it did not fulfil the requirements for validity set by the Convention. ${ }^{68}$ The Court held that the reservation was not of a general nature, as is required by Article 57(1), and there was no 'brief statement of the law concerned' ${ }^{69}$ as is required by Article 57(2). The Court clarified its stance on whether the silence of other member States meant that the reservation was valid when it stated that 'the silence of the depositary and the Contracting States does not deprive the Convention institutions of the power to make their own assessment' ${ }^{70}$

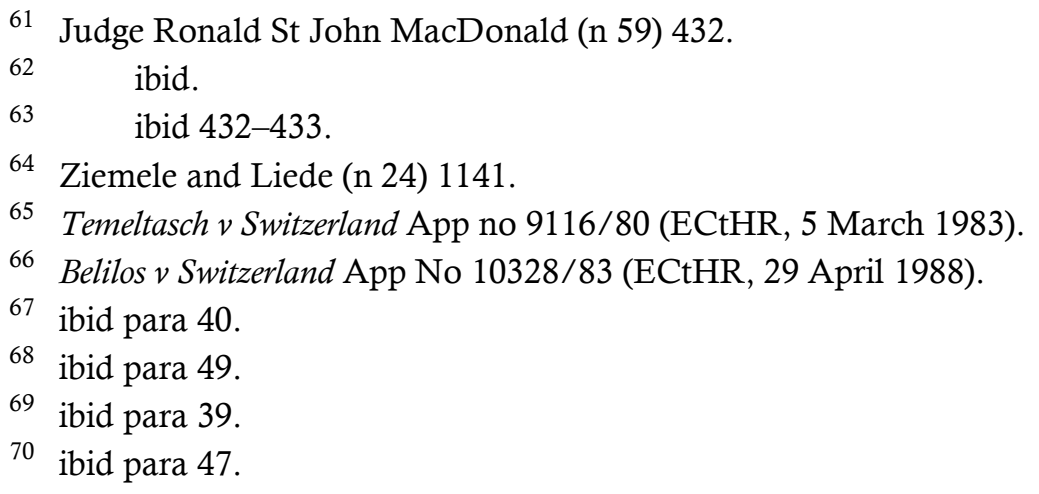


The consequences of the invalidity of the reservation were that the ECtHR adopted the severability approach and declared that 'it is beyond doubt that Switzerland is, and regarded itself as, bound by the Convention', ${ }^{71}$ in spite of the fact that its reservation was not taken into account. The court made the distinct choice to choose severability over opposability, as Switzerland argued that its reservation was valid by virtue of the fact that it had not been objected to by any of the other member States. ${ }^{72}$ Thus, the court chose to hold Switzerland to the treaty without the benefit of its interpretative declaration.

In the Loizidou ${ }^{73}$ case, the ECtHR looked in detail at the Turkish government's declarations under then Articles 25 and 46 of the European Convention and Turkey's intention to continue to be bound by the optional clause agreeing to the Court's jurisdiction. ${ }^{74}$ Even though the ECtHR refused to take into account the statements by Turkey's representatives that post-dated the declarations, it considered the text of the declarations and concluded that the impermissible parts could be separated from Turkey's consent to accept (what was at the time) the optional clause in the European Convention. ${ }^{75}$

The ECtHR has been criticised for applying the doctrine of severability because, in doing so, it disregarded the relevant State's consent. The State consented to be bound with the benefit of its reservation, not without it. The subsequent case law of the ECtHR has not addressed this issue, arguably because, to the present day, the Belilos and Loizidou cases are still the most relevant authority on the matter. The Human Rights Committee received considerable criticism for General Comment No 24. The Comment stated that 'the normal consequence of an unacceptable reservation is not that the Covenant will not be in effect at all for a reserving party. Rather, such a reservation will generally be severable, in the sense that the Covenant will be operative for the reserving party without benefit of the reservation' ${ }^{76}$ France and the United States were the greatest critics, because the VCLT is applicable also to impermissible reservations, and the VCLT is customary international law. ${ }^{77}$ This has also been made clear by the ILC, which still regards the VCLT as the reigning hard law in relation to reservations. This leaves one with the uneasy feeling that any invalid reservation seems to be almost automatically severable according to the Human Rights Committee. The ICJ's approach will be contrasted with this before further thoughts on the matter are offered.

\section{The Approach of the ICJ}

The ICJ is the main judicial organ of the United Nations. Its empowering statutes are the United Nations Charter and the Statute of the International Court of Justice. ${ }^{78}$ The purpose of the ICJ is to settle legal disputes between States in accordance with international law. Furthermore, it provides advisory opinions on legal questions referred to it by authorised United Nations organs and specialised agencies. ${ }^{79}$ The severability of invalid reservations has been considered twice by the ICJ, in the Norwegian Loans ${ }^{80}$ and Interhande ${ }^{11}$ cases.

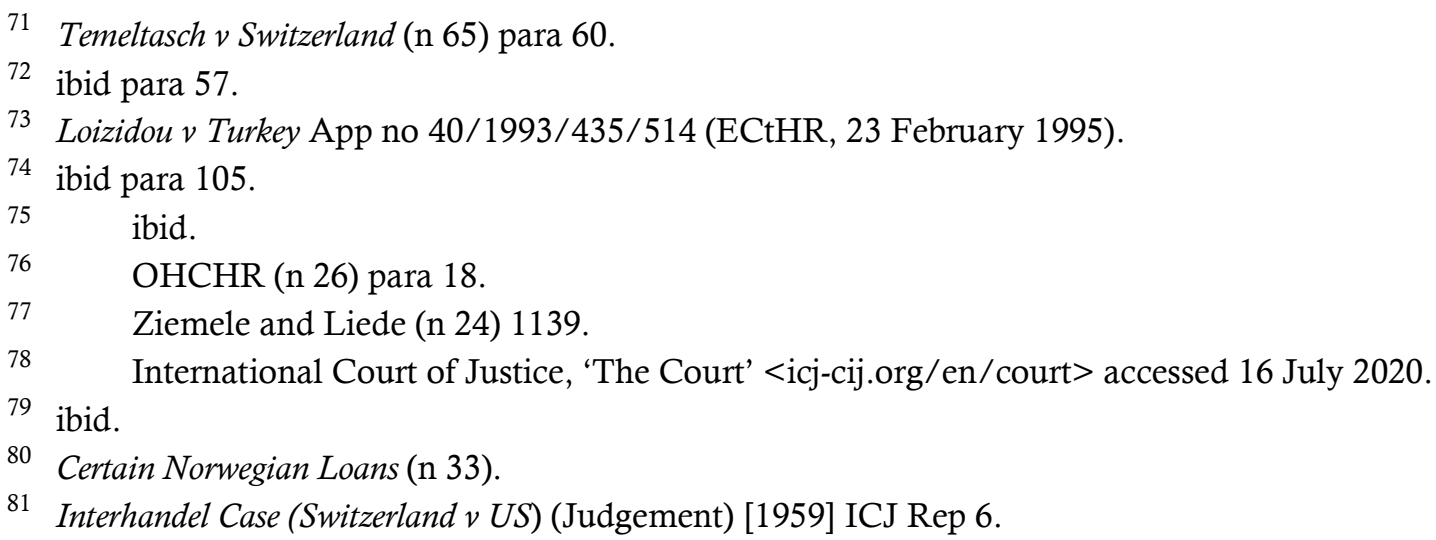


In both instances, Judge Lauterpacht gave Separate Opinions and suggested that reservations that were not essential and reservations that were invalid were severable from a State's document of ratification. The Norwegian Loans case dealt with reservations to the jurisdiction of the ICJ and the principle of reciprocity. ${ }^{82}$ It must be noted that there is a significant difference between a condition attached to an article about jurisdiction and a reservation to a treaty. However, the reasoning of the judges is still relevant and so this reasoning will be examined before explaining its relevance. As it stands, the majority of States have an automatic reservation to the jurisdiction of the ICJ. This means that States do not accept the automatic jurisdiction of the ICJ but rather accept it only when they see fit to do so. A State may thus accept or reject the ICJ's jurisdiction when a dispute arises. ${ }^{83}$ As stated in Norwegian Loans, the reservation is automatic 'in the sense that, by virtue of it, the function of the court is confined by registering the decision made by the defendant government and not subject to review by the court' ${ }^{84}$ The principle of reciprocity states that a benefit, favour or penalty granted to one State should reciprocally be granted to the other. ${ }^{85}$ The right to use this principle is found in Article 36(2) of the UN Charter. ${ }^{86}$ Using this principle, Norway, which did not have an automatic reservation to the ICJ's jurisdiction, could invoke the reservation of France. Norway then argued that it was exercising this reservation, thus excluding the jurisdiction of the ICJ. The majority of the ICJ agreed with this and held that 'it is without jurisdiction to adjudicate upon the dispute which has been brought before it by the Application of the Government of the French Republic'. ${ }^{87}$

Judge Lauterpacht argued in a Separate Opinion that the ICJ did not have jurisdiction, but for different reasons. His analysis of the reservation itself is of interest. He states:

If that type of reservation is valid, then the Court is not in the position to exercise the power conferred upon it-in fact, the duty imposed upon it - under paragraph 6 of Article 36 of its Statute. That paragraph provides that 'in the event of a dispute as to whether the Court has jurisdiction, the matter shall be settled by a decision of the Court'. The French reservation lays down that if, with regard to that particular question, there is a dispute between the Parties as to whether the Court has jurisdiction, the matter shall be settled by a decision of the French Government. The French reservation is thus not only contrary to one of the most fundamental principles of internationaland national-jurisprudence according to which it is within the inherent power of a tribunal to interpret the text establishing its jurisdiction. It is also contrary to a clear specific provision of the Statute of the Court as well as to the general Articles 1 and 92 of the Statute and of the Charter, respectively, which require the Court to function in accordance with its Statute. ${ }^{88}$

Lauterpacht argued that these automatic reservations go against the express wording of the treaty, which is to allow the ICJ to adjudicate over all matters of international law at its discretion, not at the discretion of the State itself. However, if one were to apply the usual approach of opposability in this regard, it would mean that almost every member State would no longer be party to the treaty, as the majority have reserved, in a similar manner, to the ICJ's jurisdiction. Thus, while Lauterpacht's reasoning was logical and doctrinally sound, the majority chose to uphold the State practice approach to

82 Certain Norwegian Loans (n 33) 23.

Ziemele and Liede (n 24) 1137-1138, referring to automatic reservations as 'self-judging'.

Certain Norwegian Loans (n 33) 35.

ibid 23.

ibid.

ibid 27.

8 ibid 44. 
jurisdictional reservations and allow the reservation to be enforceable. Choosing the opposite approach would have left the ICJ without much power, as there would be few member States left for it to adjudicate over.

In the Interhandel case, Judge Lauterpacht stated his view once more. This case involved a suit by Switzerland against the United States, and the US invoked its automatic reservation. The ICJ found that the objection was 'without object at the present stage of the proceedings' ${ }^{89}$ However, Judge Lauterpacht refused to sever a reservation that he felt was indispensable to the acceptance by the United States of the ICJ's jurisdiction. $\mathrm{He}$ referred once more to the 'general principle of law' relating to severability, saying that it was 'a maxim based on common sense and equity'. .0

In the Nicaragua case, ${ }^{91}$ Judge Schwebel, while noting Lauterpacht's view that automatic reservations were invalid, as was seen in the Norwegian Loans case, also made it clear that with time this argument had become less convincing, since for many years and on many occasions such automatic reservations had been treated as valid. ${ }^{92}$ This way of thinking shows that the doctrine of severability in regard to impermissible reservations was part of legal thinking before the European Commission and the ECtHR applied this approach to the European Convention. However, as can be seen from all the cases discussed, especially when comparing the approaches of the ECtHR and the ICJ, there is confusion as to exactly how reservations should be addressed. The ILC commentary adds value here, as it settles these disputes to a degree. The case law from both the ICJ and the ECtHR helps to answer the third question posed at the beginning of the paper - whether an invalid reservation cancels a party's membership to a treaty. Both Courts have regard for the importance of widespread participation and thus seem reluctant to cancel a State's membership, even though, as Lauterpacht's dissent shows us, cancellation of membership can sometimes be the most logical and doctrinally sound conclusion. In the next part of the paper, I will critically analyse the approaches of the Courts.

\section{Critical Analysis of the Approaches of the ECtHR and ICJ}

At the beginning of this paper I referenced three schools of thought used when analysing the law: the doctrinal approach, the State practice approach and the policy approach. All three have come into play in the cases discussed. Lauterpacht's dissent in Norwegian Loans ${ }^{93}$ was doctrinally sound, as it applied the law exactly as it stands and was impeccably reasoned. Practically speaking, however, if the doctrinal approach were to be followed, the ICJ would become irrelevant as it would have no member States that would be party to its Statute and thus within its jurisdiction. The majority in Norwegian Loans looked at the facts less doctrinally and more in the spirit of State practice. Reservations of this nature have been allowed to many States and have met with no objections from other States, thus they are valid and the ICJ must respect them to ensure its own survival and relevance. The ECtHR has adopted a more policy-oriented approach. By holding States to the European Convention without the benefits of their reservations, the court is trying to enforce human rights universally throughout Europe without being hampered by any reservations that may hinder this enforcement.

\footnotetext{
89 Interhandel (n 81) 26.

90 ibid 116.

91 Case concerning Military and Paramilitary Activities in and Against Nicaragua (Nicaragua $v$ United States of America) (Judgement) [1984] ICJ Rep 392.

92 Ziemele and Liede (n 24) 1138.

93 Certain Norwegian Loans (n 33).
} 
In theory, the approach of the ECtHR seems admirable because of its quest to enforce international law, especially in the sphere of human rights, but in practice it is not sustainable. International law survives on the premise that States are sovereign and that they volunteer to partake in international law with the benefit of creating their own conditions. Both the ICJ and the ECtHR understand that widespread participation is important, but the ECtHR fails to see that by binding States to agreements in the manner that it does, State participation may be lost altogether. Arguably, if States begin to feel that they may be bound by restrictions that they did not agree to when signing a treaty, they will become cautious about any participation in treaties. This will destroy the system, as treaties are not worth the paper they are written on if no member States have agreed to adhere to them.

The approach of the ICJ thus seems far more logical. Allowing automatic reservations may seem illogical when one reads Judge Lauterpacht's dissent, but automatic reservations allow for the ICJ to have member States to adjudicate over. If the ICJ had outlawed automatic reservations, this would have drastically decreased State participation. The commentary of the ILC is not a binding document in regard to reservations and was never meant to be. It was meant to provide guidelines that could be implemented to clarify reservations, but also to foster more accountability for the reservations that States choose to make. The commentary has made it clear that, as a general principle, reservations are of the utmost importance to the functioning of international law and thus should be allowed. Conditions can be put in place, but the ILC makes it clear that vagueness or room for flexibility can often be beneficial. While this flexibility may seem counterintuitive, it provides enough scope to allow for customary international law, State sovereignty and consent to be respected.

In light of the above, it is clear that the ICJ's approach is preferable to that of the ECtHR. At face value, it may seem that forcing States to adhere to human rights treaties by disregarding their reservations will enforce State accountability. In practice, it would simply eliminate States' engagement with international instruments and bodies. The ECtHR's approach runs counter to the VCLT, the ILC's commentary and customary international law by holding that States remain parties to treaties and by nullifying their reservations. The ICJ's approach, while flawed in that it does not stick to the letter of the law, is preferred because it is cognisant of the implications of its decisions on the functioning of international law.

Ultimately, despite the fact that the ICJ was dealing with a reservation to jurisdiction and the ECtHR was dealing with reservations to human rights treaties, the underlying values are the same. In essence, Judge Lauterpacht stated that automatic reservations undercut the entire purpose and meaning of the treaty as the courts do not have real power to adjudicate on their own accord. Similarly, the ECtHR sees reservations to human rights treaties as weakening the very meaning of the treaties. Thus, the core value system underlying the conclusions reached is the same. However, the ECtHR fails to see that implementing this reasoning means that you risk losing the participation of States. Without participation, international law ceases to have parties to adjudicate over and States' participation is conditional upon the protection of their sovereignty. Therefore, the ICJ's approach, as seen in the Genocide Reservations Opinion ${ }^{94}$ and Norwegian Loans, ${ }^{95}$ is the more practical approach, as it protects international law from its demise by allowing States the freedom to make reservations and it provides States with an incentive to participate.

\footnotetext{
94 Reservations to the Convention on the Prevention and Punishment of the Crime of Genocide (n 12).

95 Certain Norwegian Loans (n 33).
} 


\section{Scope for Growth}

In terms of scope for growth, one must keep in mind the ever-changing landscape in which international law finds itself. International law thrived in the aftermath of the human rights atrocities of the Second World War and the potential of nuclear war that gripped the world during the Cold War. In this era, international law broadened its scope, deepened its content and embraced a focus on individuals' rights and the idea of holding States accountable, not only to each other, but also to their citizens. ${ }^{96}$ During this time, many governance projects were realised and there was a shift towards unity and global governance on issues that affected countries worldwide. ${ }^{97}$ However, over the last few years, the world has seen rising nationalism - for example, United States policy under the Trump administration and Brexit. Scholars have argued that this rise in nationalism is a reaction to the liberal framework created by international law..$^{98}$

According to a report by the RAND Corporation, a United States non-profit thinktank that focuses on issues of global policy, the liberal international order's dominance in the global landscape has been severely threatened by various developments since $2014 .{ }^{99}$ According to the report, the events that are threatening this dominance are Russian aggression in the Ukraine, Brexit, the election of Donald Trump as US president, and the increased influence of right-wing political parties in Europe. ${ }^{100}$ However, the authors make it clear that 'this conclusion is tentative, based on trends that could reverse themselves, and not mature to the degree that some fear (or hope) ${ }^{\prime} .{ }^{101}$ This suggests that, in the future, areas of international law that are seen by some as too liberal will be vulnerable to change as tensions grow between key States in regard to how the law applies to developing global challenges.

These developments indicate that we are approaching a more difficult phase in international law, compared to what it has seen since its creation. The role of international human rights law is to influence, guide and develop the normative framework in terms of which domestic legislation is created. ${ }^{102}$ International law is changing the framework slowly and strong domestic laws are needed so that international law can make a concrete difference in a short period of time. ${ }^{103}$ Countries that have traditionally pioneered the creation of international law are relinquishing space as they step out of the global arena and focus on their domestic issues. This could result in reduced global power, tainted prestige and the rise of nationalism. ${ }^{104}$

However, in spite of the above, most of international law continues to be uncontested and assists in the daily functioning of a multitude of countries on a global stage, and States continue to rely on international law to settle disputes in a peaceful manner. As the world becomes ever more interconnected, the continued legitimacy of international law requires that the courts and drafters account for a multitude of needs and

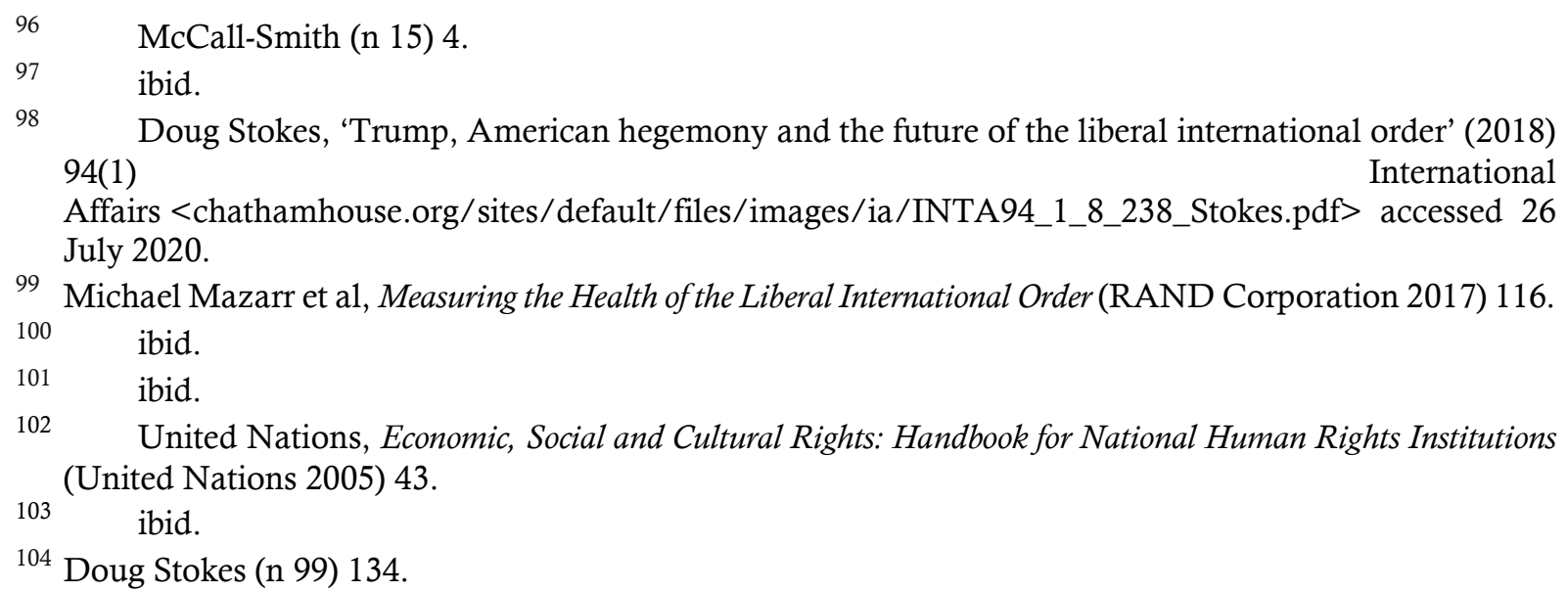


desires to maintain participation. While a degree of disagreement is par for the course and beneficial to the evolution of the international legal order, we need to remain vigilant about maintaining a balance between pleasing the key players and maintaining and developing social norms.

Human rights are intended to be universal in nature, and they are meant to apply to all people regardless of differences (for example, race, religion, nationality). ${ }^{105}$ The rise in the assertiveness of States with a sovereign approach creates risks for universal values, like sexual and reproductive rights. ${ }^{106}$ Due to their universality, these rights were often seen as liberal and idealistic. While a negative reaction to these universal rights used to be predominantly located in the developing world, the developed world is beginning to support illiberal values too. The United States and a number of European States are increasingly pushing for these universal values to be abolished. ${ }^{107}$

\section{Conclusion}

Ultimately, for international law to continue to be effective, State sovereignty must be given the utmost respect and importance in relation to reservations. With the current polarisation of the political climate, as is evidenced by traditionally liberal States leaning towards conservative values, as in Britain and the United States, a push by the ECtHR to sever reservations from treaties and still bind the State will only alienate key players from the international stage. At face value, one may be inclined to think that the stringent protection of human rights values and limiting the reservations to such values is beneficial but, in reality, this would make participation in the international framework unappealing to States as their sovereignty would be infringed. Thus, while relying on policy alone may seem favourable, it would in fact destroy the entire system of international law. Therefore, the ICJ's approach is advantageous as it understands the role of reservations in achieving participation and it also understands the State practice element. Sovereignty is sacrosanct to a country's integrity and its relationship with international law. At a doctrinal level, to adopt an approach that accommodates the demands of State sovereignty in regard to issues like automatic reservations may not be the most logical approach. However, it is necessary for the survival of the system. The ICJ has more jurisdictional standing than the ECtHR and, taking into account the move away from a global society towards a more nationalist approach in many key States, the ICJ's approach is the most pragmatic and logical. Thus, in line with the ILC commentary and the ICJ's judgements it can be predicted that the ECtHR's recent rulings will not become the international law norm and State sovereignty with respect to reservations will continue to prevail.

$*$

\section{grojil.org}

\footnotetext{
$105 \quad$ McCall-Smith (n 15) 4.

106 Eric Levenson, 'Abortion Laws in the US: Here are the states pushing to restrict access' $(C N N, 30$ May 2019) <edition.cnn.com/2019/05/16/politics/states-abortion-laws/index.html> accessed 26 July 2020. 